\title{
The Water Balance of a Small Pond in the High Arctic
}

\author{
P. MARSH and M. K. WOO
}

\begin{abstract}
Tundra ponds are ubiquitous features in the High Arctic. The water balance of one such pond situated on Ellesmere Island was found to be dependent upon the groundwater supplies from the internally-drained basin in which it was located. For the basin as a whole, evaporation constituted an important component of the water balance, accounting for over 90 per cent of the rainfall over a summer period of less than six weeks. Changes occurring in the quantity of water in the pond in response to rainfall were found to depend upon the degree of saturation of the active layer of the underlying permafrost.
\end{abstract}

RESUMÉ. Equilibre hydrologique d'un petit étang dans le Haut Arctique. Les étangs de toundras sont une particularité omniprésente du Haut Arctique. On constata que l'équilibre hydrologique d'un tel étang, situé sur l'île Ellesmere, était tributaire de l'apport en eau souterraine venant du bassin, drainé intérieurement, dans lequel il est situé. En ce qui concerne le bassin dans son ensemble, l'évaporation constituait un facteur important de son équilibre hydrologique, étant à l'origine de plus de $90 \%$ des chutes de pluie constatées sur une période d'été inférieure à six semaines. On constata que les variations de la quantité d'eau dans l'étang, en réponse aux chutes de pluie, dépendait du degré de la saturation de la couche active du pergélisol sous-jacent.

РЕЗЮМЕ. Водный баланс небольиого водоема в северной иасти Арктики. Тундровые водоемы являгтся типичной чертой северной части Арктики. Было установлено, что водный баланс одвого ив них, находятегося на $о$. Элсмир, зависит от грунтовых вод, поступающих из местного интернального бассейн. Испарение для этого бөссейна как пелого является сутцестенной компонентой водного баланса и отвечает ва более чем $90 \%$ дождевьх осадков, выпадающих ва менее чем 6-недельныи летний перпод. Было найдено; что ивменения уровня воды в водоеме в результате доэдей зависят от степени насыпения активного слоя нижележащен многолетнеи мервлоты.

\section{INTRODUCTION}

Although ponds and lakes are ubiquitous features in High Arctic terrains, and have abundant capacity for storing surface water, little information is available on their hydrologic behaviour (Church 1974). The water balance of two small lakes near Fairbanks, Alaska, has been investigated (Hartman and Carlson 1973; Kane and Slaughter 1973); but since they are located in a Subarctic region of discontinuous permafrost, the findings are not directly applicable to a High Arctic environment. In the continuous-permafrost zone of northern Alaska, Kane and Carlson (1973) found that direct precipitation and overland flow during the melt period were the major hydrologic inputs to a lake without surface-channel inlets or outlets; and in a similar environment, Brown et al. (1968) observed that all the summer precipitation was lost to evaporation in a small drainage basin.

An attempt is made in this paper to analyse the water balance of a pond

1Department of Geography, McMaster University, Hamilton, Ontario, Canada L8S 4K1. 
in the High Arctic and of the internally-drained basin in which it is located; and also to establish a relationship between the water balance of the pond and the drainage conditions of the active layer above the permafrost.

\section{STUDY AREA}

During the summer of 1975 , field work was carried out in a small internaldrainage basin, $0.5 \mathrm{~km}^{2}$ in area, located at the head of Vendom Fiord, Ellesmere Island, Northwest Territories $\left(78^{\circ} 03^{\prime} \mathrm{N} ; 82^{\circ} 12^{\prime} \mathrm{W}\right)$. A pond with a maximum area of $800 \mathrm{~m}^{2}$, formed by the thawing of ice-wedged polygons, occupies the lowest point of the basin (Fig. 1). This pond has no surface inlets or outlets, and the entire basin is underlain by permafrost at a depth $40-60 \mathrm{~cm}$, above which the movement of groundwater is therefore confined. Due to the lowness of the relief in the immediate vicinity of the pond, considerable changes occur in its surface area whenever there is a moderate change in its level.

On the basis of surficial geology and vegetation, the internal-drainage basin in which the pond is located comprises several units. East of the pond is a limestone hogback with bedrock outcrop, rising steeply to an elevation of $180 \mathrm{~m}$. Water from the hogback drains along a series of strike valleys and then down two strips of silty deposits, both well vegetated with grasses, sedges and mosses (Fig. 2). The vegetated belt continues into a depression in which the pond is situated. The

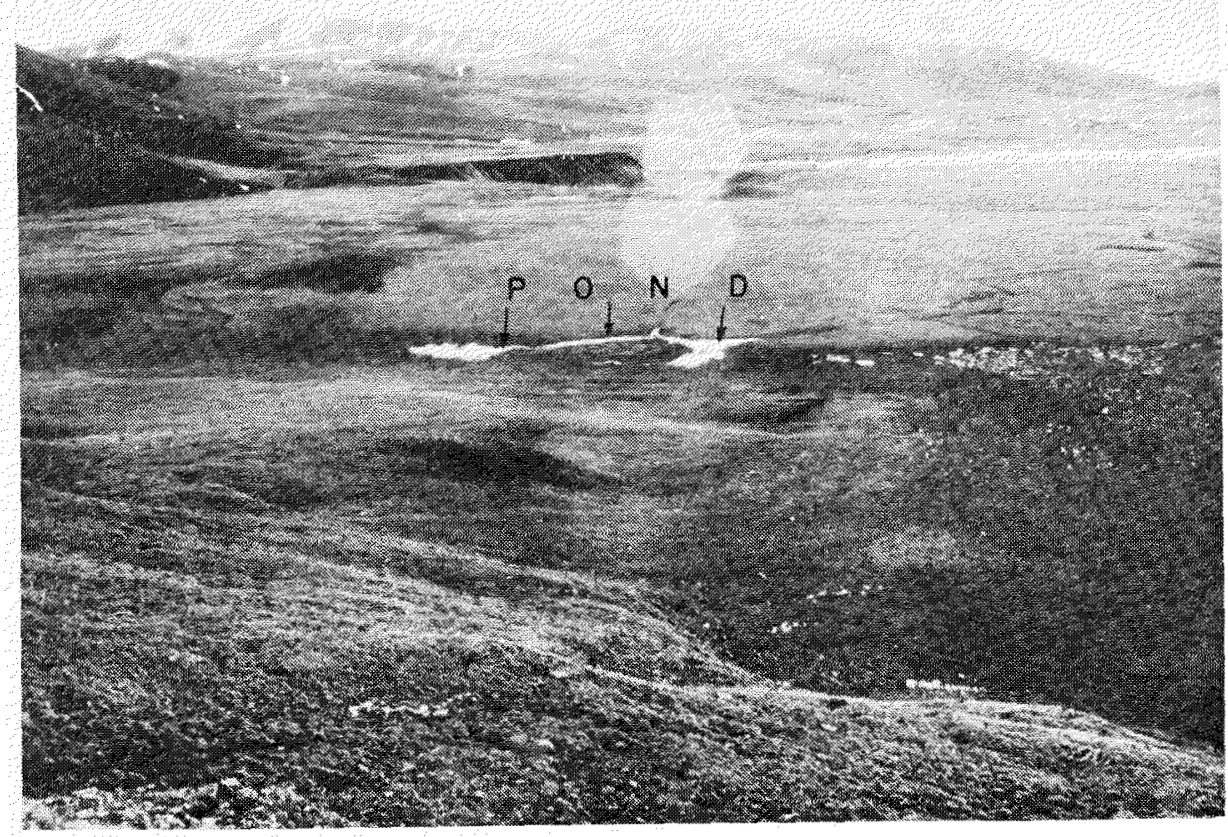

FIG. 1. Looking west from the upper part of the internally-drained basin towards the tundra pond. Two white spots above the pond are produced by lens flare, as a result of photographing against the sun. 
remaining parts of the basin consist of coarse, gravelly deposits which cover the foothill of the hogback and the surface of an alluvial terrace. The gravel areas support extensive patches of grass, Dryas integrifolia and Saxifraga oppositifolia.

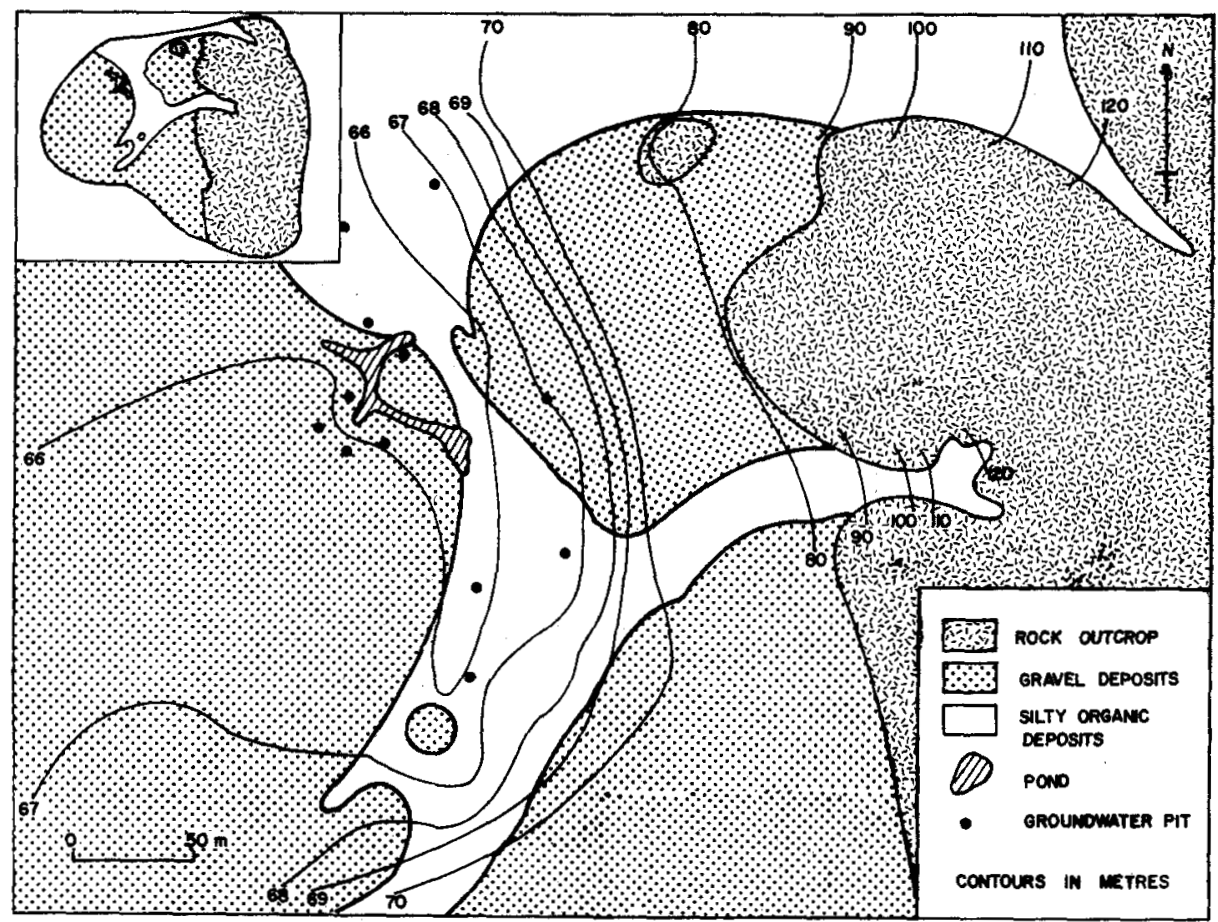

FIG. 2. Topography and surficial geology of the area around the tundra pond. Note the change in contour interval above $70 \mathrm{~m}$. The inset shows the configuration of the internallydrained basin.

\section{METHODS OF STUDY}

Rainfall was measured at two stations, one adjacent to the pond at the lowest elevation of the basin, and the other half-way up the hogback ridge at the highest (see Fig. 3). At twelve pits, groundwater level was measured daily, while the position of the frost-table was measured weekly. A water-level recorder was used to record the levels of the tundra pond. In view of the variability of the surface area of the pond which ranges from $210 \mathrm{~m}^{2}$ to $800 \mathrm{~m}^{2}$, depending on the level of the water in it, a volumetric measure of pond storage is appropriate for the computation of water balance.

Related meteorologic observations included ones of air temperature and net radiation. These data were then used to compute evaporation using Slatyer and Mcllroy's (1961) combination model:

$$
L E=\frac{S}{S+\gamma}\left(R_{n}-G\right)+\frac{\rho C_{p}}{r_{a}}\left(D_{z}-D_{0}\right)
$$

where LE is the rate of evaporation; $S$ is the slope of the curve of saturated-vapour 
pressure in relation to temperature; $\gamma$ is the psychrometric constant; $\mathbf{R}_{\mathbf{n}}$ is net radiation; $G$ is the ground heat flux; $\rho$ is the air density; $C_{p}$ is the specific heat of air at constant pressure; $r_{a}$ is the aerodynamic resistance; $D_{0}$ is the wet-bulb depression at the surface and $D_{z}$ is the wet-bulb depression at height $z$ above the surface.

When $D_{0}=D_{z}$ the second term of equation (1) reduces to zero and evaporation may be obtained as:

$$
\mathrm{LE}=\mathrm{LE}_{\mathrm{eq}}=\frac{\mathrm{S}}{\mathrm{S}+\gamma}\left(\mathrm{R}_{\mathrm{n}}-\mathrm{G}\right)
$$

$\mathrm{LE}_{\mathrm{eq}}$ is known as the equilibrium evaporation rate. The conditions under which equilibrium evaporation occurs are limited, but recent works have shown that evaporation under all conditions can be expressed as a function of equilibrium evaporation, where

$$
\mathrm{LE}=a \mathrm{LE}_{\mathrm{eq}}
$$

Various studies (e.g., Priestly and Taylor 1972; Rouse and Stewart 1972) have shown that the value of $\alpha$ lies between 1.00 for moderately dry sites, and 1.26 for saturated surfaces.

For a shallow pond on the Hudson Bay Lowland, Stewart and Rouse (1976)

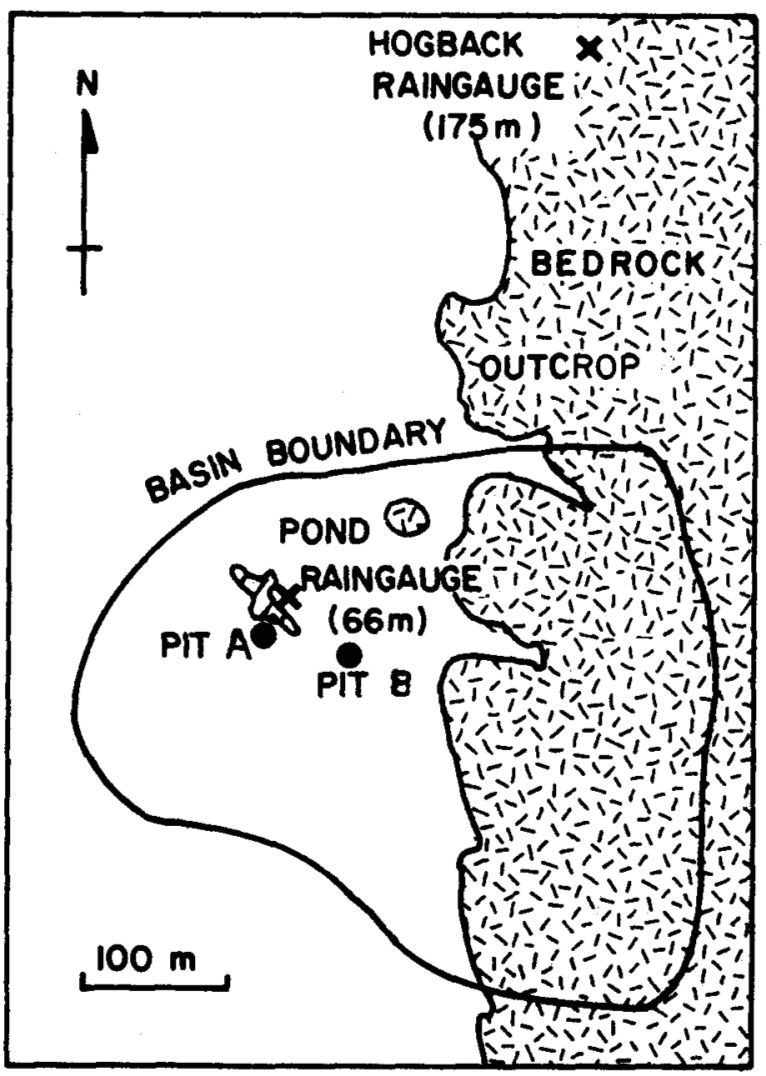

FIG. 3. Location of measurement sites. Pits $\mathrm{A}$ and $B$ are the subject of Fig. 5 . 
showed that the ground heat flux term (G) approached zero over a period of four and a half days. For a seasonal estimate of pond evaporation, therefore, the ground heat flux term may be neglected. Similarly, for a tundra site, the ground heat flux term can be ignored because it has been found to be small in comparison with net radiation (Weller and Holmgren 1974). Evaporation is then evaluated as

$$
\mathrm{LE}=a \frac{\mathrm{S}}{\mathrm{S}+\gamma} \mathrm{R}_{\mathrm{n}}
$$

In the field, $\mathbf{R}_{\mathbf{n}}$ was measured over both land and water surfaces, and $\mathbf{S} /(\mathbf{S}+\gamma)$ could be calculated from screen air temperature (Dilley 1968). An $\alpha$ value of 1.26 was used to calculate evaporation from the pond, and one of 1.0 to calculate it from the rest of the basin except the hogback area. From the latter, with its bedrock outcrops, evaporation was possible only during, and soon after, a rainstorm. In the computations therefore, evaporation was assumed to be zero one day after cessation of rainfall.

\section{RESULTS}

\section{Water balance of the pond}

The various volumes of water entering and leaving the pond can be interrelated by the equation:

$$
P_{p}+Q_{g}-E_{p} \pm \Delta S_{p}=0
$$

where $P_{p}$ is precipitation directly onto the pond surface; $Q_{g}$ is inflow to the pond; $E_{p}$ is evaporation from the pond; and $\Delta S_{p}$ is the change in volume of water in the pond. Of these terms, only $Q_{g}$, which occurred mainly as suprapermafrost groundwater, was not measured, but was obtained as the residual term of equation (5). The accuracy of this computation depends on the accuracy of determination of the other components of equation (5). Little error is to be expected in the measurement of rainfall. The combination model has been demonstrated to be reliable in the estimation of evaporation (Rouse and Stewart 1972), and the measurement of pond storage is not subject to large error. A shallow, but continuous, permafrost table precluded subsurface losses of water from the pond, and in the absence of any surface run-off, there can be no other quantities unaccounted for by equation (5).

To evaluate the magnitudes of the various water-balance components during a typical two-week period in summer, the data for the period 6-20 July 1975 were used (Fig. 4). Rainfall occurred during the first half of this period (56 per cent of total summer rainfall), but the remaining week was dry. Total rainfall directly onto the pond was $4.1 \mathrm{~m}^{3}$, while $13.6 \mathrm{~m}^{3}$ evaporated from the pond surface during the same period. With a net increase in pond storage of $24.0 \mathrm{~m}^{3}$, a groundwater inflow of $33.5 \mathrm{~m}^{3}$ was required to maintain a water balance.

These results demonstrate the importance of the groundwater contribution, representing 89 per cent of the total amount of water added to the pond. The amount of storage provided by a pond is therefore very dependent upon water supplies from the drainage basin in which it is located. 


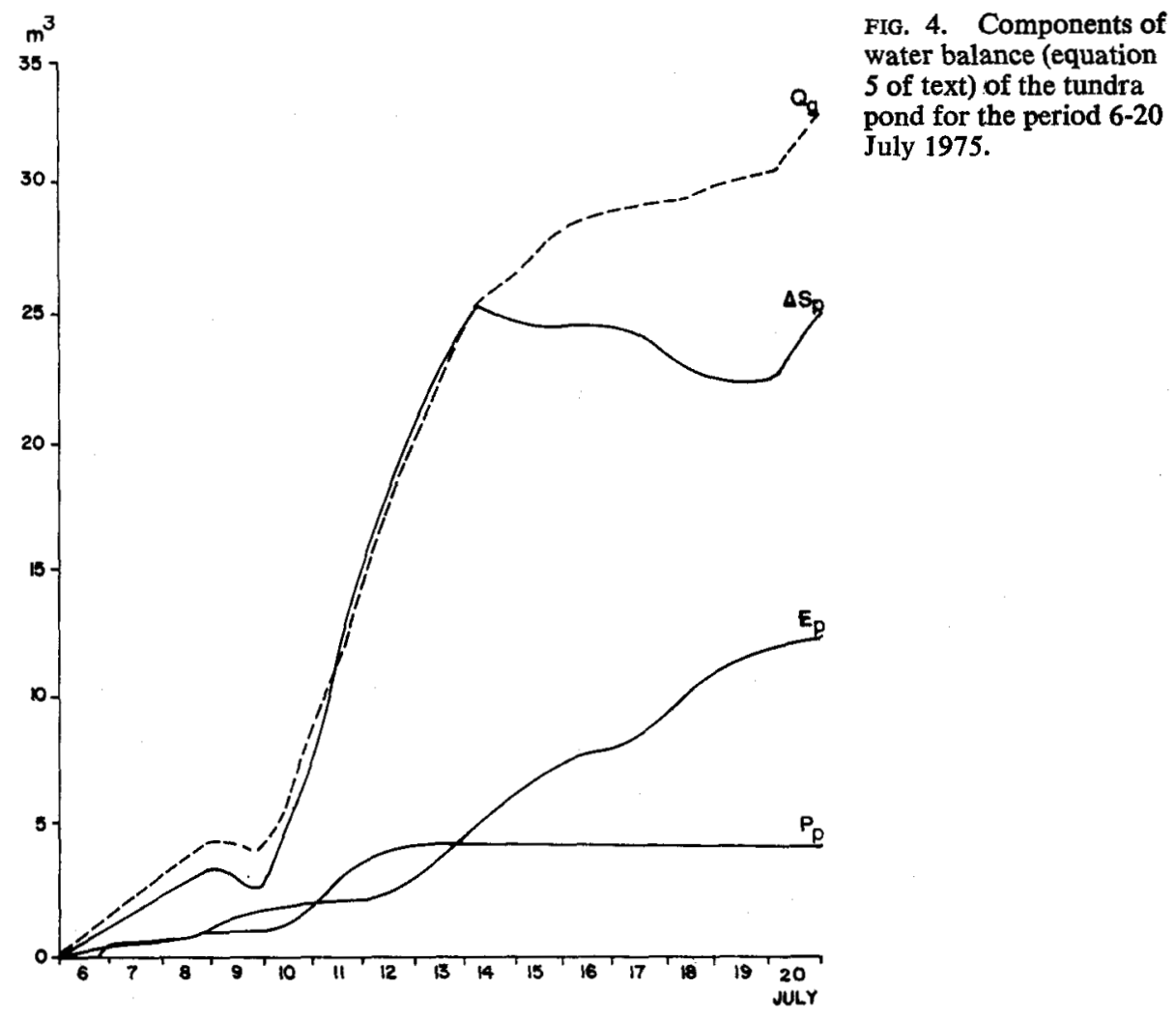

\section{Drainage basin conditions}

The dominance of groundwater input in the water balance of the pond necessitates a better understanding of the hydrologic conditions of the drainage basin in which it is located. The water-balance equation of the drainage basin can be written as

$$
P-E \pm\left(\Delta S_{p}+\Delta S_{g}\right)=0
$$

where $P$ is precipitation into the basin; $E$ is evaporation from the basin; $\Delta S_{p}$ is change in volume of water in the pond; and $\Delta S_{g}$ is change in volume of water in the active layer. All the terms were measured with the exception of $\Delta \mathbf{S}_{\mathrm{g}}$ which was obtained as a residual.

The magnitudes of the various components of the water balance were calculated weekly between 6 July and 17 August, and the results are presented in Table 1. During the two weeks when the water balance of the pond was being calculated (6-20 July), the volume of water in the basin increased by $1989 \mathrm{~m}^{3}$, indicating that there was an abundance of water in the basin after $33.5 \mathrm{~m}^{3}$ had been supplied to the pond (Fig. 4). This surplus was stored in the active layer. The quantity of water stored in the active layer fluctuated considerably during the summer, but towards the end of the study period, only eight per cent $(2.4$ $\mathrm{mm}$ ) of the total rainfall $(29.7 \mathrm{~mm})$ remained in the active layer, and 0.5 per cent 
TABLE 1. Weekly changes in the water balance of the drainage basin, 1975 .

\begin{tabular}{ccccc}
\hline & \multicolumn{4}{c}{ COMPONENTS $\left(\mathrm{m}^{3}\right)$} \\
\cline { 2 - 5 } DATES & $\mathbf{P}$ & $\mathrm{E}$ & $\Delta \mathrm{S}_{\mathrm{p}}$ & $\Delta \mathbf{S}_{\mathbf{g}}$ \\
\hline 6-12 July & 8,348 & 3,425 & +21.5 & $+4,901.5$ \\
13-19 July & 0 & 2,910 & +2.5 & $-2,912.5$ \\
20-26 July & 0 & 2,170 & -16 & $-2,154$ \\
27 July - 2 August & 3,270 & 1,935 & +48 & $+1,287$ \\
3-9 August & 218 & 1,565 & -6 & $-1,341$ \\
10-17 August & 3,061 & 1,610 & +20 & $+1,431$ \\
\hline 6 July - 17 August & 14,897 & 13,615 & +70 & $+1,212$ \\
& $(29.7 \mathrm{~mm})$ & $(27.2 \mathrm{~mm})$ & $(0.14 \mathrm{~mm})$ & $(2.4 \mathrm{~mm})$ \\
\hline
\end{tabular}

of the rainfall was added to the pond, while 91 per cent $(27.2 \mathrm{~mm}$ ) had evaporated. Hence, within one and a half months of summer, by far the greater part of the water precipitated into the basin was lost by evaporation; and so the significance of evaporation in the water balance of Arctic basins is confirmed (Woo 1976).

\section{Discussion}

Of particular interest is the variation of the quantity of water stored in the pond in relation to rainfall. Fifty-six per cent of the total rainfall received during the study period (6 July to 17 August) fell between 6 July and 12 July, and this led to an increase of $21.5 \mathrm{~m}^{3}$ in the quantity of water stored in the pond. In contrast, only 22 per cent of the total rainfall fell between 27 July and 2 August, but water stored in the pond increased by $48 \mathrm{~m}^{3}$ (Fig. 4). Such variations can be accounted for by examining the drainage conditions of the active layer of the underlying permafrost. Prior to $6 \mathrm{July}$, water levels in the observation pits were low (Fig. 5), indicating that most parts of the active layer were dry. The bulk of rainfall was therefore used up in increasing the quantity of water in the active layer. Between 27 July and 2 August, however, the active layer was mostly saturated, and a high level of water was prevalent in the lower parts of the basin. Since, therefore, the additional rainfall could not be retained in the active layer, it found its way into the pond (Fig. 6).

The above example serves to illustrate the close relationship maintained between the quantity of water stored in the pond and the active-layer drainage conditions. It also shows that the antecedent moisture-storage conditions of the active layer exert a strong influence on the degree of change in the quantity of water stored in the pond in response to rainfall.

\section{CONCLUSIONS}

The conclusions which can be drawn from the present study of the water balance of a small High Arctic pond and the drainage basin in which it is located may be summarized as follows:

(a) Evaporation is an important component in the water balance of the internally-drained basin, accounting for over 90 per cent of the summer rainfall in less than one and a half months during the study period. 


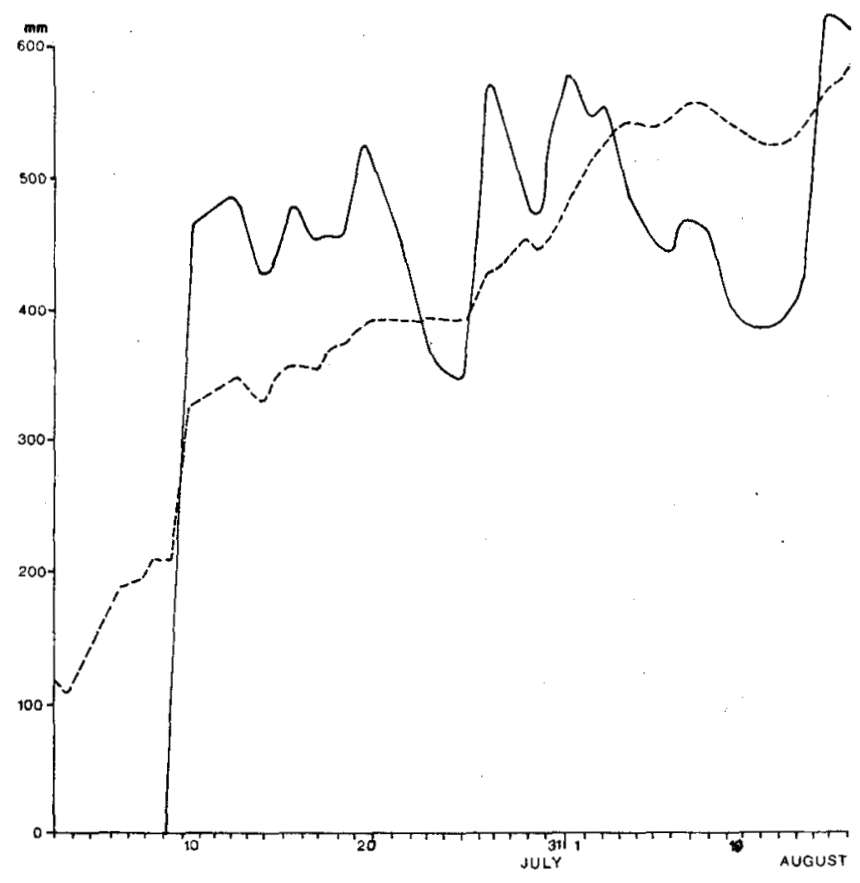

FIG. 5. Water level in Pit A (represented by broken line) and Pit B (continuous line) over the study period. The location of the pits are indicated in Fig. 3.

(b) Groundwater flow in the internal-drainage basin was the major source of water-supply to the pond.

(c) The change in the quantity of water in the pond in response to rainfall depended upon the degree of saturation of the active layer. When the latter was dry, the bulk of basin rainfall was used to replenish the groundwater stored in the active layer. When the active layer was fully saturated, however, additional rainfall could not be retained in it, and therefore flowed into the pond.

Hydrologic studies of tundra ponds should therefore be undertaken in conjunction with an investigation of the drainage conditions of the active layer surrounding them.

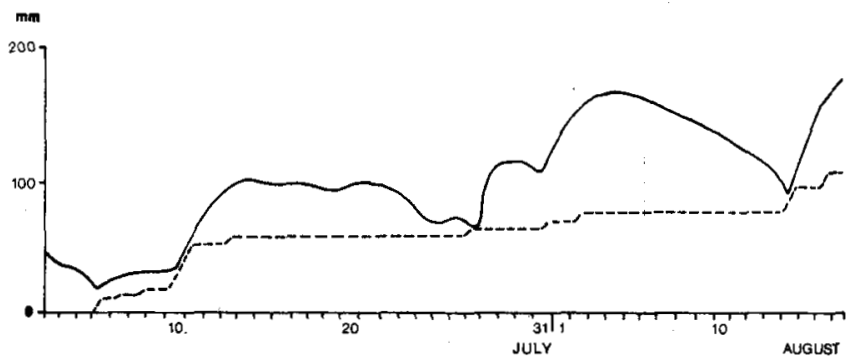

FIG. 6. Cumulative rainfall (represented by broken line) and water level (continuous line) of the tundra pond over the study period. 


\section{ACKNOWLEDGEMENTS}

We wish to thank S. B. McCann for facilitating the field programme. This work was supported by a contract from the Glaciology Division, Environment Canada, and by a research grant from the National Research Council of Canada. The logistical support of the Polar Continental Shelf Project, Department of Energy, Mines and Resources, is also gratefully acknowledged.

\section{REFERENCES}

BROWN, J., DINGMAN, S. L. and LEWELLEN, R I. 1968. Hydrology of a drainage basin on the Alaskan coastal plain. U.S. Army, Corps of Engineers, Cold Regions Research and Engineering Laboratory, Research Report 240.

CHURCH, M. A. 1974. Hydrology and permafrost with reference to northern North America. Proceedings, Workshop Seminar on Permafrost Hydrology. Ottawa: Canadian National Committee for the International Hydrological Decade. pp. 7-20.

DILLEY, A. C. 1968. On the computer calculations of vapour pressure and specific humidity gradient for psychrometric data. Journal of Applied Meteorology, 7: 717-19.

HARTMAN, C. W. and CARLSON, R. F. 1973. Water balance of a small lake in a permafrost region. University of Alaska: Institute of Water Resources (Report IWR-42).

RANE, D. L. and CARISON, R. F. 1973. Hydrology of the central Arctic river basins of Alaska. region. University of Alaska: Institute of Water Resources (Report IWR-41).

and SLAUGHTER, c. W. 1973. Recharge of a central Alaska lake by subpermafrost groundwater. Permafrost, North American Contribution to the Second Intermational Conference. Washington, D.C.: National Academy of Sciences. pp. 458-62.

PRIESTLY, C. H. B. and TAYLOR, R. J. 1972. On the assessment of surface heat flux and evaporation using large scale parameters. Monthly Weather Review, 100: 81-92.

ROUSE, W. R. and STEWART, R. B. 1972. A simple model for determining evaporation for high-latitude upland sites. Journal of Applied Meteorology, 11: 1063-70.

SLATYER, R. D. and MC ILROY, I. C. 1961. Practical Microclimatology. Paris: UNESCO. STEWART, R. B. and ROUSE, W. R. 1976. A simple method for determining the evaporation from shallow lakes and ponds. Water Resources Research, 12: 623-8.

WRLLER, O. and HOLMGREN, B. 1974. The microclimatology of the Arctic tundra. Journal of Applied Meteorology, 13: 854-62.

woo, M. K. 1976. Evaporation and water level in the active layer. Arctic and Alpine Research, 8: 213-7. 